\title{
Recuperação e Detecção de Norovírus (Nov) Humano e Norovírus Murino (Mnv-1) de Amostras de Presuntos
}

\author{
Isabelle da Silva Luz (I), Fabiana Gil Melgaço (I), Matheus Ribeiro \\ da Silva Assis (I), Marize Pereira Miagostovich (I) \\ (I) Fiocruz - Fundação Oswaldo Cruz (Av. Brasil, 4365 - Manguinhos, Rio de Janeiro - CEP: \\ 21040-360)
}

\section{Resumo}

A manipulação e armazenamento inadequados de presuntos podem tornálos potenciais transmissores de gastroenterites alimentares. Dentro deste contexto, Norovírus (NoV) é responsável por pelo menos $50 \%$ dos surtos de gastroenterite no mundo inteiro, em que apenas poucas partículas (1100) são suficientes para causar doença. Atualmente, a detecção deste patógeno em alimentos é realizada primariamente por métodos moleculares, uma vez que ainda não há um método padronizado disponível para detecção de NoV nestas matrizes. Norovírus murino (MNV-1) é morfológica e geneticamente similar a NoV humano, sendo testado como controle do processo de detecção de NoV em algumas amostras de alimentos. Desta forma, este trabalho objetivou avaliar metodologia de recuperação de NoV GII e MNV-1 a partir de amostras de presunto baseada no uso do polímero polietilenoglicol (PEG) e detecção destes vírus por qRT-PCR. Amostras de presunto obtidas do comércio local foram artificialmente contaminadas com a inoculação direta de $250 \mu 1$ de suspensão fecal quantificada de $\mathrm{NoV}$, bem como com aproximadamente $10^{7}$ cópias genômicas de MNV-1. Para cada concentração viral avaliada, foram realizados ensaios em triplicata e controles negativos foram incluídos em todos os experimentos. As amostras de presunto $(25 \mathrm{~g})$ foram lavadas com tampão de eluição (Tris-Glicina pH 9.5) incluindo 3\% de extrato de carne e concentradas com solução de polietilenoglicol (PEG

\footnotetext{
Referência:

Isabelle da Silva Luz, Fabiana Gil Melgaço, Matheus Ribeiro da Silva Assis, Marize Pereira Miagostovich.Recuperação e Detecção de Norovírus (Nov) Humano e Norovírus Murino (Mnv-1) de Amostras de Presuntos. In: Anais do 12을 Congresso Latinoamericano de Microbiologia e Higiene de Alimentos - MICROAL 2014 [= Blucher Food Science Proceedings, num.1, vol.1]. São Paulo: Editora Blucher, 2014.

DOI 10.5151/foodsci-microal-012
} 
6000). Para extração do genoma viral, foi utilizado o kit QIAmp kit mini viral (Qiagen, Valencia, CA, EUA) de acordo com as instruções do fabricante. Transcrição reversa (RT) foi realizada utilizando-se iniciadores randômicos, cujo DNA complementar foi aplicado na detecção de NoV e MNV-1 por qRT-PCR de acordo com protocolo descrito em Kageyama et al. (2003) e Baert et al. (2008), respectivamente. Usando precipitação por PEG, a eficiência de recuperação de NoV GII variou de $0,06 \%$ a $0,37 \%$, e de $0,14 \%$ a $1,29 \%$ para recuperação de MNV-1. As taxas de recuperação inferiores a 5\% são muito provavelmente devido a componentes inibidores tais como lipídios e polissacarídios presentes na própria matriz alimentar, que parecem desenvolver um papel importante na eficácia de detecção de vírus. Embora a identificação de vírus em alimentos seja um desafio, outras metodologias serão testadas minimizando a liberação de inibidores de PCR, visando recuperar este patógeno.

Palavras-Chave: Norovírus humano, Norovírus murino, Polietilenoglicol, Presunto, qRT-PCR

Agência de Fomento: Conselho Nacional de Desenvolvimento Científico e Tecnológico (CNPq) 